This is the Accepted Version of Anastasiadis, F. and Poole, N.D. (2015). 'Emergent supply chains in the agrifood sector: insights from a whole chain approach' published by Emerald in Supply Chain Management: An International Journal 20(4): 353-368:

http://www.emeraldinsight.com/doi/abs/10.1108/SCM-08-2014-0259

Accepted Version downloaded from SOAS Research Online: http://eprints.soas.ac.uk/20750/

\title{
Emergent supply chains in the agrifood sector: insights from a whole chain approach
}

\author{
Foivos Anastasiadis (Department of Mechanical Engineering, Aristotle University of \\ Thessaloniki, Thessaloniki, Greece) \\ Nigel Poole (SOAS Centre for Development, Environment and Policy, University of London \\ (SOAS), London, UK)
}

\begin{abstract}
Purpose of this paper: This paper reports research into emergent supply chain management (SCM) practices in a context in which the imperative for business development requires efficient inter-firm collaboration. It explores the way key supply chain (SC) actors perceive entrepreneurial opportunities and evaluates their SC processes.

Design/methodology/approach: A whole chain approach, employing qualitative methods, was used to investigate retail, wholesale and production links, with a special focus on small businesses which predominate in the agrifood sector. The methodology employed is of vital importance to understand the complexity of the sector and the interdependencies among stakeholders.

Findings: Results suggest several SC malfunctions originating in diverse strategic planning practices and different entrepreneurial mentalities which hinder the process of emergence from traditional to more modern chain configurations. The fact that the nature of new opportunities in the agrifood sector (e.g. organics) was poorly understood, obstructs further development of the agrifood sector. Other key findings suggest problematic flows of information within the SC and minimal trust among stakeholders.

Research limitations/implications: Sampling constraints suggest that caution should be exercised in extrapolating these conclusions elsewhere. Nonetheless, further investigation employing similar approach should be applied in a wider context not only in Greece but in other similar economies characterised by nascent SCs.
\end{abstract}


What is original/value of paper: The study investigates the entire SC of a vital sector for numerous SMEs, with lessons for diverse emerging agribusiness economies. Insights, not only for the direct SC stakeholders but also for policy-makers, could serve to unlock the potential of such sectors and also the exploitation of new opportunities in emerging markets which can be stifled by stagnant sectoral structures and conservative business attitudes.

Keywords: whole chain approach, agrifood, emergent SCM, SMEs Article type: Research paper 


\section{Introduction}

Proponents of theories of economic growth and development have often looked to progression through a series of structural stages as a means of explaining how change occurs, and how sophisticated and efficient markets emerge from rudimentary forms of economic exchange. An influential contribution in the mid-20th century was that of Rostow (1960), who envisaged five linear stages of growth phenomena associated with transition from a traditional society to an age of high mass consumption. While Rostow identified important elements of growth theory, his model has lapsed, having failed on many accounts, not least because a) the linear model assuming simple technology transfer was a poor description of many idiosyncratic but successful pathways whereby so-called modern economies emerged from within so-called traditional societies; and b) failed to offer a prescription for approaches and interventions to promote economic growth and development.

In contrast, North's contribution (1990), founded on substantive historical research, identified stages of development in which managing transaction costs was a determinant of the emergence of productive economic exchange. Context rather than technology was important. For North, the key to continuous incremental change, i.e. the emergence from traditional to modern, is the emergence of increasingly complex institutional contexts - i.e. formal laws and informal norms and business codes - that make possible new bargains and compromises between the players. This he referred to as re-contracting. The nature of the 'players' was also important: the immediate instruments of institutional change are entrepreneurs, market actors who take advantage of new opportunities, reshaping business structures and relationships.

In business, continuous change is assumed: Lee's studies of major international firms over a number of years suggested three dimensions that can be understood as benchmarks of sustainable SC efficiency (Lee, 2004): such SCs are a) agile - constituent firms react speedily to sudden changes in demand or supply; b) they adapt to changing market structures and strategies; and c) exhibit a purposeful alignment of the interests of all the firms in the supply network. These three qualities suggest that dynamic rather than static structures, processes and relationships within a SC are essential features of a response to new opportunities and challenges.

To a considerable extent, North's development concept coincides with an increasing sophistication in market structure and behaviour that is described in the literature as 'emergent SCM'. This literature includes a number of explorations of changes in SCs. For example, Lorentz et al (2013) conducted case studies of firms in 'advanced markets' which were expanding their operations into 'emerging markets', in order to understand how emerging market characteristics affected the food supply networks of such internationalising firms. Among their findings was the importance, firstly, of institutions and structures, and secondly, of strategies of primary and secondary market actors, in enabling the formation of new SCs and networks. They highlighted four factors that affected the emergence of SCs, being chain structures and actor capabilities; control of the quality of goods and services; infrastructure and processes to manage new products; and - specific to the internationalisation 
of these chains - the geographic configuration of supply networks. The significance of the entrepreneurial activity of key market actors was highlighted likewise by Huang et al (2013).

SCM is one of the most important management functions for achieving long-term competitive advantage, and several of its practices are significantly correlated with SC performance (Chen and Paulraj, 2004). The purpose of this article is to understand how new market opportunities can be exploited by the emergence from traditional market systems into modern and efficient SCs. Within this research arena, the objective is to analyse the predisposition and interactions of market players at each stage through the whole chain from production and wholesaling to retail and consumption in terms of upgrading SC practices from traditional to more efficient structures and behaviour. The Greek citrus sector, with significant opportunities for exploiting market potential for higher value produce such organics, is the case used to explore these dynamics of emergent SCM.

The literature review highlights the importance of the key concepts involved in this study and establishes a relationship between the literature gaps and the research questions. Methodologically, analysing all market players including farmers, collective organisations, different types of wholesale traders and retailers surpasses SC analyses which address simple inter-firm dyadic relationships, by examining business characteristics and linkages through the chain. This we call a 'whole chain approach'.

For the empirical work, three sets of studies employing qualitative methods cover the Greek organic citrus SC from production to retail. The focus was to explore the interdependencies among SC actors in unlocking new opportunities through the development of SCM strategies and capacities - especially for SMEs - in the agrifood sector.

In this research, an indicator of the "jointness" of business strategies, which is the flows and sharing of information about market demand and production conditions, is analysed to evaluate the extent to which the SC responds to market opportunities for organic quality and environmental sustainability. Hence, this paper explores the information attributes and strategies of chain actors in order to assess SC constraints to small firm engagement in new market opportunities. The findings illustrate how the entrepreneurism needed to exploit new opportunities in emerging markets can be stifled by stagnation in sectoral structures and conservative business attitudes. We suggest that a manifesto for small business development ultimately depends not on the external environment or policy interventions, but on fostering certain fundamental human predispositions and learning processes. Entry points for innovative action are identified in the recommendations.

\section{Literature Review and Context}

A holistic exploration of the agrifood sector involves numerous issues and complicated interactions among diverse stakeholders. For a tractable research design this scope was reduced by focusing on specific vital dimensions of emergent SCM. Therefore, we initially reviewed previous studies concerning key SC performance concepts related to exploitation of new opportunities, for emerging economies in general and for the case-specific Greek agrisupply chain. Only those concepts having a vital role in both conditions were further 
reviewed, resulting in a significant narrowing of the scope of the study. The last step of the review process involved identification of unambiguous gaps in the literature and formulation of the respective research questions.

\section{Emergent SCS}

In many developing and emerging economies, inter-firm linkages are haphazard, market strategies and collaboration are uncoordinated. In such conditions SCM is in its infancy (Iyer et al., 2013). The principles of joint planning and action to ensure the best provision to consumers and the best returns to supply firms underlie efficient SCM. Hawkes summarizes important business challenges for the food industry in emerging economies, which are to better understand firm perceptions of products and market opportunities, and how individual business strategies and incentives are aligned throughout SCs (Hawkes, 2009). For small firms in emerging economies, research is necessary to understand what are the obstacles to enhancing sustainable chain performance (Etemad, 2013), and what are the appropriate strategies and structures, such as information sharing and collective organization, that might ease firm entry and overcome the SC constraints.

Typically a firm's strategy is formulated at senior management level and then applied throughout the organization. However, small-medium enterprises or family businesses which are the vast majority of actors in the food industry in emerging economies are highly dependent on a single decision-maker (Feltham et al., 2005). Even in the agricultural sector where new collective entrepreneurial strategies are emerging, the nature of these organizations generates decision-making problems due to the diverse concerns of their social base (Poole and Donovan, 2014, Ortiz-Miranda et al., 2010). Issues such as trust of the owner/manager with respect to the supply network members (Brunetto and Farr-Wharton, 2007) and the quality of relationships amongst SC participants (Vasileiou and Morris, 2006) are of vital importance.

The recent work of Sharifi et al (2013) has highlighted three critical elements for developing new integrated product-market-supply chains: SC strategy and design; product design and development; and market strategy. Similarly, in their study of the catering sector in the UK, Brindley and Oxborrow (2014) identified the importance of relationship-building between suppliers, intermediaries and customers, and of reverse information flows, in aligning sustainable food supplies with changing market demands. They proposed a model of an 'emergent aligned SC' with two drivers for, and indicators of, alignment. These were 'lean and resource efficient' and 'local and seasonal' - contingent on market demand. Pullman and Dillard (2010) similarly identified the importance for a sustainable 'values-based' beef cooperative of flows of quality information from production to the end consumer. Their case study is an example of how a specialized agrifood SC for a premium product emerged through collaborative chain processes.

The effect of emerging market characteristics on SCM is unquestionable, even concerning international food manufacturers entering such markets. Several adjustments should take place to ensure adaptation in these conditions (Lorentz et al., 2013; Hsu et al., 2013). 
Regarding Greek agrifood SCs, and similar emerging SCs, organic farming can be considered as a sustainable new opportunity for many stakeholders.

There is a gap in the literature regarding emergent SCs and the sustainable exploitation of new opportunities. Aiming to narrow this broad topic, further review of the relevant concepts follows.

\section{Agri-supply chains in Greece}

It is timely to explore the reasons why the domestic supply industry in Greece is failing to respond to new market opportunities. SC research in Greece is limited, but the relatively undeveloped nature of the primary sector is reasonably well documented. The food sector is a vital part of the EU economy in which small- and medium-sized enterprises (SMEs) especially are of great importance, since they make up $99 \%$ of this sector and account for $50 \%$ of its turnover (EU, 2012). Efficient and competitive domestic SCM is an imperative for agribusiness (Rong et al., 2011, Sartorius and Kirsten, 2007), and requires small and large firms alike to adopt entrepreneurial strategies in terms of product development, firm management and interfirm linkages (Rauch et al., 2009). Thus, for the agrifood sector, sharing information among producers, traders and retailers about agricultural production practices, sources of supply, channels of distribution and consumer preferences are essential practices for an efficient response to new market opportunities.

One agrifood sector where new opportunities exist is the organic market for fresh produce (Smith, 2006) where value addition through certification can offer considerable price premia in a discerning consumer market. Organic agriculture, like other premium enterprises, has created many business opportunities throughout the world (Simon et al., 2012, Little et al., 2010). Like many market niches, it is not for everyone. The literature suggests that a focus on sustainable SCs and collaboration and relationships are strategically important SCM concepts (Ashby et al., 2012). The Swedish organic milk SC is an excellent case of a sustainable business cycle (Svensson and Wagner, 2012), and a potential model for the emergence of the Greek organic citrus SC.

It is the nature of entrepreneurism to recognize and shape such new opportunities - and make a profit. Nevertheless, entrepreneurism does not characterize the Greek agrifood sector as a whole (Avlonitis and Salavou, 2007), which, like in many countries, is upheld by aging farmers and traditional practices.

The Greek case is highly relevant to less developed agricultural economies in terms of the agricultural supply side. The sector is characterised by small farm size, a relatively high contribution to employment and the economy, limited investment and value added, and import dependence where there is potential comparative advantage. While there are no publicly available data or actual indicators of the level of SC development, a priori knowledge suggested that the Greek agricultural sector can be said to be 'emergent', among the less developed in the European Union, and comparable to many developing agricultural economies. The latest European Commission data depict a relatively underdeveloped and 
stagnant Greek agricultural sector, with fruit in general and citrus in particular making a significant contribution (European Commission, 2013, except where indicated):

- farm size is among the smallest (5.8 hectares utilized agricultural area per holding, cf EU27 mean 15.0 hectares $^{1}$ )

- a high share of the civilian working population employed in agriculture $(12.2 \% \mathrm{cf}$ EU27 mean 5.2)

- the share of agriculture in the GDP was 2.8\% in 2012 (cf EU27 1.2\%)

The latest data show an aging profile of Greek farmers that is more marked than most other EU28, and a widening unfavourable gap between agricultural input and output prices since 2005 (European Commission 2014).

The current depression is manifest in data which show that indices of real output prices for agricultural products $(2005=100)$ were, at 83.8 , the lowest in the EU28 in 2013 with the exception of Latvia (European Commission, 2013 , Table 4, p.26). The propensity to import is high, nevertheless $(11.9 \%$ share of imports of food and agricultural products in imports of all products, cf EU27 5.7\%).

The fruit sector contributed $19.9 \%$ of agricultural output in 2013. Citrus accounted for $1.2 \%$ of utilised agricultural area in 2011, the same as Italy and (more than Spain at 1.0\%, second only to Cyprus at $2.5 \%$. As far as organics are concerned, there has been almost no recent change in the number of certified and policy-supported organic and in-conversion farms (2008: 23,$372 ; 2012: 23,433)$, notwithstanding a reported increase in area (2008: 317,824 ; 2012: 462,618). On the demand side, the Greek share of household consumption expenditure devoted to food, beverages and tobacco as proportion of total consumer expenditure of households was high at $20.6 \%$ in 2012 (cf EU27 16.5\%).

Other researchers have considered Greek food SCs to be traditional food chains (Bourlakis et al., 2012). Their structures and processes deviate from those considered typical of SCM widely encountered in advanced economies. Changing business culture and practices from traditional market behaviour to more efficient and coordinated SCs is a challenge for many incumbent enterprises. Thus the opportunities presented by the potential expansion of a premium organic agriculture sector in Greece make a particularly interesting and timely case. The Greek fruit and vegetable market for years has offered potential for organic production, according to the Ministry of Agriculture (Vranaki, 2009), yet organic citrus, for example, demonstrates limited expansion as a food category (Willer and Yussefi, 2013). Previous studies indicated several malfunctions in Greek agrifood SCs, especially with respect to information flows (Anastasiadis and Poole, 2007), collaboration (Matopoulos et al., 2007), SME collective action issues (Lamprinopoulou et al., 2006) and the incoherence of individual firm strategies among the main stakeholders (Bourlakis and Bourlakis, 2001). For these reasons, citrus was chosen as the unit of SC analysis because of its market potential and its importance in local production and consumption. Thessaloniki was chosen, as Greece's

\footnotetext{
${ }^{1}$ EU27 is EU28 less Croatia.
} 
second city, with food distribution linked to major domestic supply regions in the north of Greece.

\section{Research questions}

Commitment and trust are vital issues in ongoing relationships (Morgan and Hunt, 1994, Herscovitch and Meyer, 2002). For instance, committed employees motivated by an organization's values and objectives can address the challenge of shifting to a more entrepreneurial focus, grasping new opportunities and implementing sustainable strategies (Wu and Pagell, 2011). However, such approaches usually are affected by concerns for shortterm growth rather than long-term competitiveness, due to cost and resource constraints ( $\mathrm{Wu}$ and Pagell, 2011). A similar trade-off is often observed between short-term profitability and long-term environmental sustainability, involving high uncertainty and risk (March and Simon, 1993, Kahneman et al., 1982).

While trust and commitment are held to improve chain performance, Nyaga and co-authors (2010) argue that collaborative activities, such as information sharing and relationship 'effort', are required to achieve effective levels of trust and commitment. Strategic long-term relationships and integration with suppliers is one of the key aspects in managing SCs, including choice of the right suppliers (Prajogo et al., 2012). Barratt (2004) highlighted the need for a greater understanding of cultural, strategic and inter-personal elements that contribute to collaboration.

Different types of relationships can impact on the operation of firms and their capacities to innovate (Soosay et al., 2008). In the agrifood sector the configuration of relationships is of great importance, in particular the way different chain actors are organized to strengthen their position (Bijman, 2006). In well-developed SCs, small producers often are organized horizontally (Adamowicz and Lemanowicz, 2006) and such horizontal collaborations, especially when based on commitment, are vital for small-medium retailers (Ghisi et al., 2006). However, there are several constraints to collaborative organisation in the agrifood industry that depend on the specific structure of the sector and the product type (Matopoulos et al., 2007).

The literature reviewed above underscores the interrelated concepts of coordination and collaboration as major factors in exploiting new market opportunities. In an emergent SC context, however, these concepts have not been explored thoroughly and their significance in relation to the emergent status of a SC remains unknown. Therefore the first research question aims to investigate both these concepts and their relevant interactions among SC actors:

\section{How is inter-firm coordination configured in an emergent supply chain context?}

Both market and entrepreneurial orientation are key concepts that determine to what extent a firm is responding to new opportunities. Market orientation defines whether a firm's strategy is driven by customers/competitors, and reflects the firm's tendency to adopt the marketing concept (Slater and Narver, 1994). An entrepreneurial orientation determines whether firm 
growth depends on the identification and utilization of unexploited market opportunities and its priority to elaborate on such opportunities (Shane and Venkataraman, 2000). Typically entrepreneurial orientation is measured by assessing a firm's commitment to strategic decision making on market intelligence, yet in small businesses it depends more on the entrepreneurial predisposition and commitment of the firm's owner (Brockman et al., 2012). Additionally, in small businesses, market and entrepreneurial orientation are complementary and both boost a firm's profitability (Baker and Sinkula, 2009). An example of entrepreneurial orientation is the willingness to grasp new product-market opportunities (Lumpkin and Dess, 1996), which for the food industry includes the growth of the organic sector.

From a business, managerial and organizational perspective, information can be defined as data made useful for decision making (Wong et al., 2012, Taylor and Fearne, 2009, Schermerhorn, 2002). Knowledge that contributes towards recognizing new (sustainable) opportunities consists of one type of such information, the sharing of which has a significant effect on innovation capability (Yang, 2011). Moreover, the way information flows and is utilized in an organization is key to performance and of strategic importance to understand the factors influencing the development of relationships among SC partners. For instance, Liberman-Yaconi and co-authors (2010) highlighted the essential role of information in the strategic decision making process of micro-firms. One example of information flows within advanced SCs is RFID technologies (Sarac et al., 2010). However, in economic entities such as the localized production systems in Greece, while modern technology is present, most product and demand information flows not through advanced technologies but through human interaction: mostly word of mouth. Thus, the role of individuals and personal relationships within such networks is increased (Dimitriadis and Koh, 2005).

The literature suggests that developed SCs thrive due to firms' ability to recognize new market opportunities and share that knowledge among their members. As highlighted above, commitment to exploit such opportunities is also required. Therefore, the second research question aims to explore information flows at a SC level:

What is the level and role of knowledge, information sharing and commitment for new market opportunities in emergent SCs?

To sum up, previous studies suggest that entrepreneurial strategies of small firms which prevail in emergent economies, such as those investigated here, are constrained in the ability to recognize new opportunities and develop the relevant SC structures and processes required to move from traditional markets through emergence to efficient SCM. The literature fails to explain how the constraints are specifically addressed in emergent SCs. This paper aims to fill this gap.

\section{Methodology}

Approaches for analysing SCs commonly employ transaction cost economics (Williamson, 1979, Williamson, 1975) or resource-based views of the firm (Wernerfelt, 1984), yet they do not explain the network dynamics in a non-dyadic context. A whole chain approach has 
several advantages when complicated networks are analyzed; it is preferred, for example, for analyses of food quality issues (Roth et al., 2008). A holistic approach in the case of the food industry allows assessment of horizontal relationships among multi-tiered suppliers as well as vertical chain relationships (Mena et al., 2013). Its main advantage compared to the dyadic approach is the ability to capture complexities of networks (Choi and $\mathrm{Wu}, 2009$ ).

A qualitative case study approach was considered appropriate to investigate each level of the chain and address the "how" or "why" research questions necessary to elucidate individual firm strategies and perceptions (Yin, 2012, Silverman, 2006). Such an approach is suggested when the investigator has little control over events, and also allows for the retention of meaningful characteristics of real-life events such as organizational processes (Yin, 2003).

The approach here analysed the SC linkages in a successive manner from producer, through wholesaler to retailer. The illustration in Figure 1 is a conceptual and methodological map, incorporating the key concepts emerging from the literature review and captured in the research questions. These involved exploring the extent to which the entrepreneurial strategies of SC actors raised the level of coordination and collaboration through the establishment of joint objectives and strong SC relationships. Simultaneously, the flow of information regarding the knowledge of new market opportunities and the commitment to grasp them, were also explored. This procedure consists of a loop that explores SC integration and new market opportunities knowledge/commitment for each SC member, as these are presented in the left part of the figure (i.e. three different types of both retailer and wholesaler and two different types of producers). 
Figure 1 The Whole Chain Approach

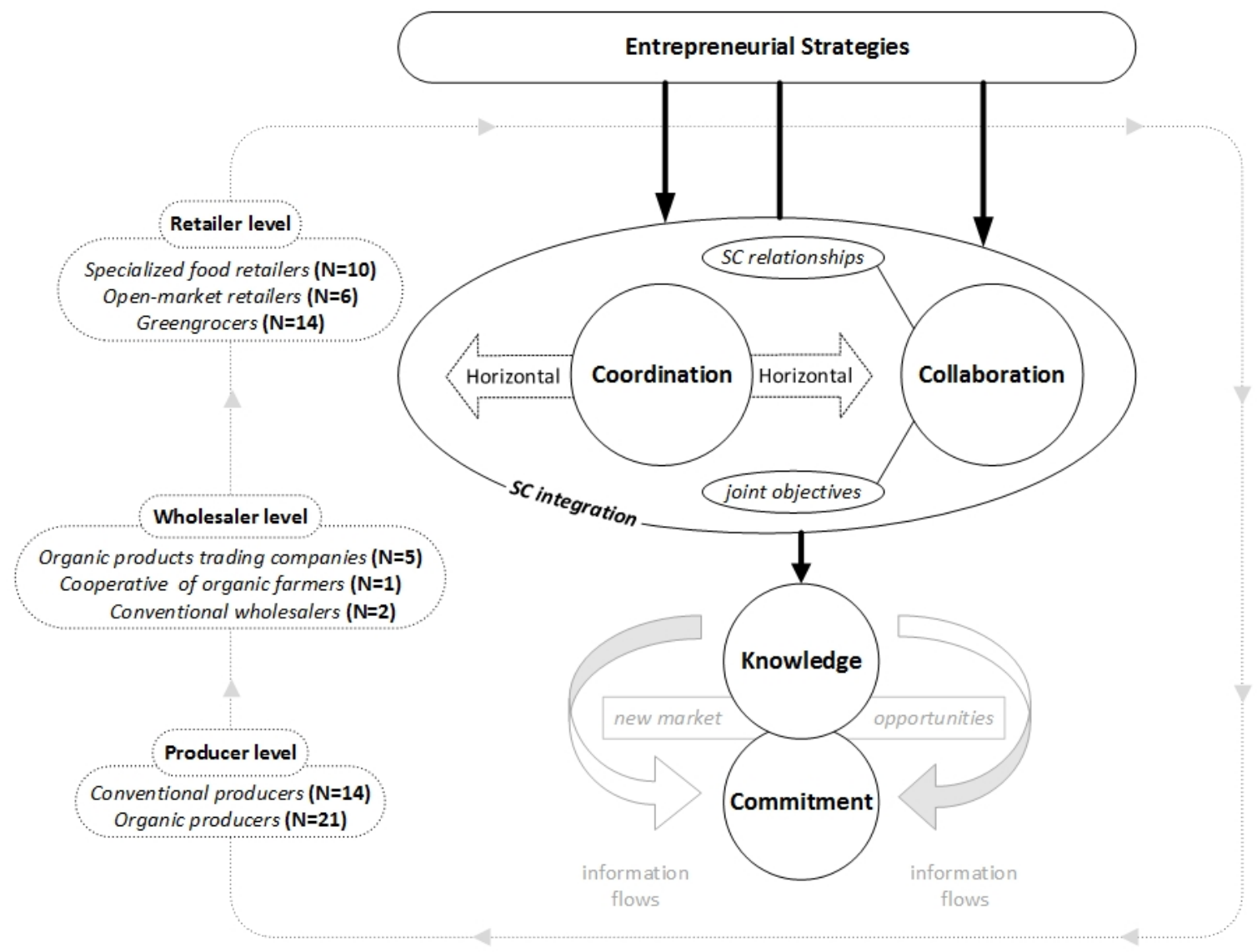

\section{Research Design}

A basic interview guide served as the instrument to delineate the questions which were adapted for different types of firm at each level of the chain. Closed and open-ended questions were used, aiming to capture the stakeholders' entrepreneurial strategies, and interviewees were encouraged to elaborate their thoughts. A total of seven different interview guides were developed: three for retailers (greengrocers, open-market retailers and specialized stores retailers); two for wholesalers (trading companies and cooperatives); two for producers (organic and conventional citrus). An indicative interview guide per SC level (i.e. retailers, wholesalers and producers) is available in the Appendix. The data collection for all case studies resulted in 73 valid interviews (from a total of 85), further details of which are presented below.

Taking into account the guidelines by Saldaña (2013), the map of the whole chain approach and the related interview guide, a structured list of themes for analysing the data was developed. Examples at this stage included attitudes and perceptions regarding organic products, as well as the business orientation of different types of SC stakeholders. Each transcript was examined thoroughly and further coded into appropriate sub-themes at every SC level, reflecting the views and experiences of the interviewees. Indicative sub-themes per SC level were: (a) production level: awareness of organic farming practices, motivation to select crop/farming system, and selling strategies; (b) wholesale level: relationships with 
suppliers/customers, awareness of organic product attributes, motivation to work with new products; and (c) retail level: motivation for, and/or experience of selling organic products, supply shortages, knowledge of consumers' attitudes. The structured list of themes eventually evolved into more than 150 detailed sub-themes. Each sub-theme was then examined to compare the interviewees' comments and triangulate the findings. The aim was to identify patterns in the data, and to highlight the entrepreneurial strategies of each SC stakeholder.

\section{Sampling}

As noted above, the research was undertaken in Greece, since the current status of the agrifood sector exemplifies the type of emergent SCs under investigation. Furthermore, the organic food market could be perceived as a sustainable new opportunity for most stakeholders of the agrifood sector. Thus, sampling from Greece satisfies both criteria (emergent SCs and specific new opportunities). Data concerning the retail and wholesale level were collected from the greater metropolitan area of Thessaloniki, which was chosen as the study location due to its significance as the second city of Greece. The data with respect to the cooperatives and producers were collected from the region of West Greece, a major supply area for Thessaloniki and representative of the SC investigated. More detailed sampling information for each SC level follows.

\section{Retail level}

For the purpose of increasing validity, the judgmental sampling (Malhotra, 2010) approach had two main objectives: first, to include every type of fruit and vegetable trader, and second, in each type to select the most powerful based on trading volumes. For the retailing sector 30 semi-structured interviews were conducted: 14 greengrocers, 10 open-market retailers and six specialized organic and health food stores. With respect to greengrocers, open-market retailers and specialized stores, and due to the absence of sales figures, the sample selection was based on observation data (about the size and position of the store) and snowballing data from focus group discussions with wholesalers at the Wholesale Vegetable Market of Thessaloniki (WVM), that supplies the vast majority of retailers.

\section{Wholesalers}

No secondary data were available concerning the wholesalers. Therefore, the sampling frame was based on empirical data collected through the retailer interviews, since among other things they were asked about their suppliers of organic products. In Thessaloniki organic products can reach retailers through several alternative channels, the most important of which was from organic producer cooperatives, through organic trading firms to the WVM (ICAP, 2011). For the wholesaling sector eight semi-structured interviews were conducted including different type of traders. In detail, there were five organic products trading companies representing the majority of this type, and one cooperative of organic farmers. Finally, two conventional wholesalers from the WVM were selected, one because he traded citrus exclusively and the other due to his leading position in the market.

\section{Producers}


The sample frame at producer level aimed to include both conventional and organic citrus farmers. Producers from the region of West Greece were selected as the operational population, since based on the empirical data from the interviews with wholesalers, that region supplies Thessaloniki and was representative of the SC under examination. In total, 35 semi-structured interviews were conducted, with 21 organic and 14 conventional producers from every important county in terms of citrus production. Snowball sampling technique was employed in each county in order to select a diverse range of producers in respect of scale of production, proximity to Thessaloniki, and engagement with primary sector organizations.

To protect respondents' identities and assure confidentiality, the names of individuals, firms and other organizations were changed. Results are arranged in four sets, one for every research question, employing data from each SC level. We provide certain quotes from the interviews due to their value in defining, exemplifying, reinforcing and elaborating the interpretation of events (Glaser and Strauss, 1968).

\section{Results and Discussion}

The structure of this section is based upon the dominant themes revealed during the analysis and then correlated with the most relevant research question(s). More specifically, subthemes of awareness of organic farming practices at the production level, awareness of organic products' attributes and knowledge about demand organic food at both wholesale and retail level, were featured under the principal theme knowledge and were connected with the first research question. The following sub-themes were grouped under the principal theme of commitment: producers' motivation to select crop/farming system, wholesalers' motivation to work with new products and retailers' motivation and/or experience of selling organic products.

An analogous pattern applies to themes related to the second research question: sub-themes relationships with suppliers/customers and selling strategies at all levels (i.e. production, wholesale and retail) were grouped respectively under the principal themes collaboration and coordination.

Key findings from each level of the SC resulted not only in drawing a holistic picture for every issue, but also in highlighting the interactions among stakeholders. Hence, crucial insights concerning the SCM of small firms in the Greek agrifood sector were identified. Thus, the whole chain approach enabled the investigation of each stakeholder involved in the $\mathrm{SC}$, and validation of findings by triangulating data.

\section{Knowledge}

The interviewees' awareness of the nature of organic product attributes and farming practices was assessed via a categorization of their knowledge relating to the definition of organic agriculture. This resulted in three different types, those who were respectively: unaware; somewhat aware; and fully aware. 
Table 1

Knowledge relating to the definition of organics for every SC actor (in percentage)

\begin{tabular}{lccc}
\hline & Unaware & Somewhat Aware & Fully Aware \\
\hline Retailers: & 21 & 58 & 21 \\
Greengroceries & 60 & - & 40 \\
Open markets & - & 50 & 50 \\
Specialized markets & - & & \\
Wholesalers: & 100 & - & 80 \\
Organic & & & - \\
Conventional & 10 & 38 & 52 \\
Producers: & 29 & 64 & 7 \\
Organic & &
\end{tabular}

The results presented in Table 1 suggest that those involved more in the organic food sector had a more thorough knowledge of the organic concept, while the others (such as conventional wholesalers and producers) were not. The latter type of small firm could potentially grasp the entrepreneurial opportunity of the organic market yet their lack of knowledge not only prevents such an option but makes them appear as opponents. Quotes from a conventional wholesaler verify the level of doubt:

"I don't think that it is feasible to produce organic products and basically there is no postharvest treatment for organics" and

"It [the organic sector] is a fraud, not 100 percent but in 95 percent. There are a few real organic products, but they are lost among the cases of fraud!"

On the other hand, the interviewees' knowledge about the demand for organic food was contradictory. Greengrocers considered that there was no significant demand for organic products, with 43 percent stating that it is a niche market. Open market retailers had no clear opinion and specialized store retailers were equally divided among those claiming a significant demand and those claiming not great but sufficient demand.

At a wholesale level the differences were clearer: conventional wholesalers recognized a trivial demand, while organic wholesalers were targeting the market more effectively. Almost all of the organic wholesalers were to some extent export-oriented, mainly to Central European markets. Nevertheless, organic wholesalers were also supplying the Greek market; in fact, half of them were mainly working with that market. It is noteworthy that concerning the domestic demand they were not using any direct information from end-consumers but only information derived indirectly from the retailers and from other wholesalers. A quote from a major organic wholesaler illustrates the extent of the wholesalers' power over information: 
"No, I don't need to survey consumers. Demand is a very certain thing and there is nothing that research can offer to me about the Greek market. I will tell you something that might sound a little bit strange: 'we (wholesalers) are continuously shaping the market'. For the European or global markets, yes, I am reading market research and I am trying to keep up to date. However, for the Greek market I will make two-three phone calls plus the feedback from the retailers and I will have a full and clear picture really fast".

Finally, both conventional and organic producers (over 60 percent) stated that they had no information about consumer demand and in general no market insights. A quote from a conventional producer highlights their information-dependency upon traders:

"We get that information only through the trader, that is, from what the traders are telling us. But the thing is that you cannot trust them - they tell you whatever they like."

Regarding knowledge, therefore, key findings suggest limited awareness of both production practices and lack of a supportive regulatory environment to meet the organic category requirements. The data also reveal a blockage of market information sharing since it highlights a limited availability of consumer demand information among SC actors. This was an outcome of their simultaneous exploration and the triangulation of the respective findings at every SC level. Such a critical finding unveils one of the key issues concerning the low performance of agrifood SCs and recognition of new opportunities such as organic food markets: information sharing constraints. In general, for efficient and effective SCM, an unobstructed flow of information is a prerequisite, but especially in cases such as producerexporter relationships in the agrifood sector (Jraisat et al., 2013), the level of information sharing is even more important. To that end, the current study contributes to the literature findings that underline the importance of information sharing in emergent SCs.

Further analysis suggests that the blockage of information is related to the power of certain stakeholders. Most of the firms involved in the organic food industry are small firms, yet some are more powerful than others due to their key position in the SC. Wholesalers/traders are positioned between producers and retailers, thus having the opportunity not just to block any information sharing but to refine or fabricate vital information for their benefit. These findings confirm previous studies suggesting a relationship between information sharing and power asymmetry in inter-organizational relationships (Cheng, 2011). However, in emergent SCs the source of power for certain actors comes from their key position within the chain (i.e. those located between retails and producers); in other words, the main issue is the structure of the chain. This is a notable result: previous studies have underscored similar power-related issues among retailers (Taylor, 2006), but have not hitherto implicated wholesalers or middlemen as powerful information brokers.

\section{Commitment}

At a retail level, investigating the experience of selling organic products revealed a strong commitment to organics only among 15 percent of the greengrocers and 50 percent of the specialized retailers, while open market retailers were unconvinced by the organic farming 
practices. However, this commitment was based on ethical, not economic reasons such the recognition of a business opportunity. One of the interviewees said:

"I really believe in these products, I really believe the whole thing; that is the reason I am working with these products. It is clearly because of personal and ethical reasons, and not a business opportunity."

Exploring wholesalers' motivation to work with new products provided insights regarding their commitment to organics, which was related to their degree of 'involvement' in the organic food industry. Organic wholesalers were fully committed and driven by a combination of ethical values and business opportunity. For instance an organic trader said:

"The reason I decided to work with organics is a combination of a business opportunity with a positive action for the environment and the health of the consumers."

Conventional wholesalers were sceptical about the overall organic philosophy, so they clearly did not recognize any business opportunity and apparently there was no such commitment. One comment was:

"Greece is not yet ready for organics, there are no products, no producers and the market is really small."

Producers' motivation to select organic crop and/or farming systems suggests that they also followed a similar pattern to that of the wholesalers. Those growing organics recognized the business opportunity and were significantly committed. The vast majority stated that a crucial motive to be involved with organic farming was better sales of their product: better prices (95 percent) and better supply conditions ( 81 percent). Producers of conventional products recognized the same opportunity but to a lesser extent, that is better prices ( 57 percent) and better supply conditions (43 percent). In addition they acknowledged several constraints such as production and market knowledge issues.

Concerning the principal theme of commitment, results suggest that the development of the agrifood sector and therefore prosperity of the firms involved is linked to individuals' efforts to grasp new market opportunities. The fact that there is a strong commitment of some SC actors and weak or no commitment of others reveals their different perceptions towards new opportunities such as organic food. Naya and co-authors also highlighted similar behavior with respect to different perspectives on buyer-supplier collaborative relations (2010). However, the current study emphasizes that the differences are in a direct relation to the extent to which every SC actor recognizes the organic market as a new opportunity. The whole chain approach reinforces this argument, since it allows contrasting of different points of view of several SC actors at various levels. For example, conventional wholesalers not involved in the organic business failed to see an opportunity (see quote above), thus they had a completely different viewpoint compared to other SC actors involved in both organic and conventional food markets. This is consistent with previous findings about recognizing and realizing sustainable development opportunities - such as organic food-related business (Patzelt and Shepherd, 2011). From a SC perspective this results in the absence of common 
goals, a critical prerequisite for effective SCM with balanced benefits for both the SC as a whole and the individual actors involved (Li and O'Brien, 1999).

\section{Collaboration}

The nature of business relationships among $\boldsymbol{S C}$ actors varies at every level in the organic food SC but also within the same level. At a retail level, different sourcing outlets shape different trading mentalities. Retailers from specialized stores were sourcing from independent wholesale companies trading organics (operating outside the WVM), while both greengrocery and open market retailers were sourcing - almost exclusively - from the WVM. Over 90 percent of the latter type of retailers undertook a so-called "go around" behavior: each retailer would walk round the market from one wholesale supplier to another in order to evaluate the products and prices currently available and then decide where and what to buy. Thus, they were characterized by their effort to study the supply and achieve a good deal. Moreover, this type of retailer was further divided into two subtypes: the "bargainers" (those who may have maintained a group of preferred suppliers, but still were continuously bargaining) and the "regular suppliers" (those who have strong business relationships with some suppliers and tended to engage in recontracting). A remarkable quote from one of the "bargainers" clarifies the nature of their business mentality:

"A relationship between wholesaler and retailer does not exist: the wholesaler wants to sell his products at the maximum price and the retailer wants to buy at the minimum, so you never trust anyone in this business. Trading is cheating, end of story."

At the wholesale level there was also a variety of business relationships among SC actors. Both types of organic wholesalers claimed an essential criterion in selecting suppliers/producers to be the excellent cooperation between the two parties, meaning good communication, trust and reliability. However, among conventional wholesalers, despite the fact that they also claimed to invest in long-term business relationships, the majority of their suppliers/customers (more than 70 percent) were 'occasional'. This reflects the way the WVM functions as a spot market with many traders, huge volumes and variety of products, and intense competition.

The critical criterion for the producers (both organic and conventional) was the reliability of the trader (cited by over 85 percent). This is mainly rooted in bad past experiences, such as loss of money or cheating, a factor that also limits any possible development of long-term relationships between producers and traders. Producers claimed opportunistic behavior from the traders and additionally mentioned that a reliable trader is more important even than the price received. This combination reveals the reasons behind the short-term relationships between producers and traders:

"Choose a trader you are sure that will pay you. I don't care about the price; there is only one criterion: he must have money!"

The key finding about the principal theme of collaboration reveals a problematic situation in relation to joint objectives in emergent agrifood SCs. The type of established inter- and intra- 
tier relationships with shared objectives is a phenomenon rarely observed in this sector. Examining the entire SC in a single study was vital in unveiling this problematic collaboration. This mainly derives from a lack of trust among SC actors: retailers do not trust wholesalers, producers do not trust traders, and so on. Trust is a vital issue in buyer-supplier relationships, it influences both information sharing and collaborative planning (Cai et al., 2010) and especially in small firms has a moderating role in collaboration-related decisions (Brunetto and Farr-Wharton, 2007). With minor exceptions, a short-term trading mentality shapes SC relationships, thereby restricting significantly any proper development of the firms involved.

\section{Coordination}

As already highlighted in the previous section, a lack of collaborative strategies characterized retailers, thus the horizontal coordination within that level was minimal. Further exploration of retailers' selling strategies revealed that over 80 percent of specialized store retailers underlined this absence of horizontal coordination. However, this was not concerning coordination among themselves but the lack of horizontal coordination among their producersuppliers. Similarly, organic wholesalers mentioned essential sourcing obstacles due to problematic network arrangements for organics combined with the involvement of numerous non-professional producers. Producers were well aware of this issue, in fact more than half of them (both organic and conventional) proposed the formation of farmer groups as a way to address most of their current problems (that is supply issues and low prices):

"We need a group of farmers with organizational structure, that is people in the group with negotiation skills and knowledge of market conditions."

Nonetheless, all of them agreed that this would be very unlikely to happen due to the lack of a cooperative spirit:

"This is never going to work, since in Greece as you already know two people working together is nice, three are too many!"

In other words, at the production level there was a paradox; all the farmers understood that collaboration could improve their competitive advantage but it was impossible to achieve that. An explanation came from an acting president in a local cooperative:

"Everybody one way or the other is happy with the current situation, they don't admit it but they are. Everybody makes money so far from citrus in our region, they don't admit that but I believe we are much better off than other regions. As a result, we haven't been forced to work together, to cooperate. If, in the future we reach a point where we will not be able to sell, then we will probably work together!"

Concerning the collaborative strategies and horizontal coordination in the agrifood sector (the principal theme of coordination), minimum trust among SC stakeholders was the decisive factor. There were different perspectives regarding coordination at every SC level, yet examination of the entire SC (i.e. whole chain approach) underscored trust issues as a common denominator. While the importance of horizontal coordination is widely recognized 
in the literature, (for example Burt and Sparks, 2003 in the UK, and Adamowicz and Lemanowicz, 2006 in Poland). However, the majority of the stakeholders in Greece either did not acknowledge the issue or in case they did, it was about a different level of the SC. Only producers realized the importance of horizontal coordination, yet they were insufficiently motivated to put that in action. Apparently, producers were satisfied with the current status (see quote from the cooperative's president above) thus no driver exists for horizontal coordination aiming at achieving better prices or accessing new markets. In contrast, Chapman and Corso (2005) argued that a key motivation for coordination and collaboration is the opportunity for wider access to competencies, an argument that does not apply in the Greek agrifood SC.

\section{The Emergent Supply Chain}

The essence of the study is encapsulated into the findings concerning the following four themes: (1) knowledge of new market opportunities, (2) commitment to grasp them, (3) collaboration and (4) coordination of the SC actors towards joint objectives. The first two findings address RQ 2 and the second two concern RQ1. Further analysis of the key findings on each theme highlights those aspects particularly related to the emergent nature of the SC under examination. Concerning the first theme, problematic information sharing obstructs any access to SC advancements and eventually to new markets (e.g. due to ineffective or absent sharing of consumer demand-related information). Consequently, several key members of the chain, especially from the production level, have limited or no opportunity at all to evolve, thereby sustaining the emergent character of the SC. For the minority of the SC players that recognise new opportunities, the analysis of the second theme suggests that commitment issues constrain such initiatives. This reinforces the perception that the current emerging status of the SC is highly unlikely to change without commitment towards new opportunities. Likewise, both third and fourth themes point in the same direction: collaboration and coordination for common goals are prerequisites to shift a SC from an emergent to a more developed form. Minimal trust among SC stakeholders implies weaknesses in intra/inter-level chain relationships and discourages any possible cooperation that could lead to development of competitive advantages for the SC as a whole.

The ultimate outcome from the analysis of all four themes is that they constitute inherent factors of a sequential process which characterizes an emergent SC. The value of this finding is significant for the entire SC since it reveals the mechanism behind a process of collective emergence and therefore provides critical insights to overcome the obstacles. The recommendations/implications based on these findings (presented in the following section) will apply to the entire SC as well individual firms.

\section{Conclusions}

The motivation behind this study was to explore the processes within and conditions for emergent SCs. The research questions aimed to investigate firstly, the role of knowledge sharing and information flows in relation to managers' commitment to exploiting market opportunities such as developing organic products; secondly, how firm commitment translates into collaborative supply chain strategies, and the extent to which collaborative 
strategies result in coordinated supply chain structures and relationships. These concepts were studied from an entrepreneurial perspective, since such an approach is the fundamental prerequisite to shift from an emergent to a more developed SC configuration. In typical cases of emergent SCs, such as the Greek agrifood industry, the evidence suggests that the SC processes reflect the conditions of typical emergent SCs. The evidence suggests that the entrepreneurial orientation needed to adopt key supply chain management concepts and implement enhanced practices requires further development in the Greek organic citrus chain. Apart from isolated cases, the owner-managers of the small farms and firms did not demonstrate an entrepreneurial commitment to the opportunity that organics presents, and individualism prevailed. A trading mentality persisted rather than a culture of business relationships and recontracting; knowledge and information were private, and individual conceptions of organic products and convictions about market opportunities were mixed and contradictory. Business strategies were in most cases far from complementary and incentives for joint action were rare.

As a yardstick of supply chain management, the flows of accurate, relevant information linking SC partners - or rather, independent actors - were mostly ineffective. The perceptions and strategies of different individuals and firms showed little commonality or "joint interest" along both horizontal (for example, grower organization) and vertical (producer-wholesalerretailer) dimensions. The key relationship function of linking producers to the consumer market is mostly subverted by a trading mentality. In the current case, supply chain management will be ineffective without horizontal as well as vertical cooperation. This seemed inimical to many of the interviewees, growers and traders alike. Together with other structural constraints such as unwillingness to collaborate and awkward logistics, the lack of coordination was likely to subvert individual attempts to innovate. It is easier to export than to address domestic demand. A frank assessment is that the new opportunity concepts (e.g. organics) were poorly understood, market information was partial and inaccurate, enduring business relationships were the exception, standards and assurance mechanisms were weak at best, and trust was minimal; in short, supply chain management was absent.

Exceptionally, among the organic specialists there were examples of chain structures and relationships which were coordinated and collaborative, suggesting that the dominant trading mentality was not immutable: there were individuals and firms committed to information searching and sharing, repeated contracting and collective strategies. These tendencies illustrate the phenomenon and dimensions of emergence.

\section{Conceptual contribution}

Emergent SCs are considered as those in a process of transition from rudimentary local markets to modern industrialized economies. The analysis of such SCs enables the definition of several emergent SC characteristics:

- at one pole, atomistic market players whose exchange activities and pricing behaviour are based on spot markets, with limited or no relationships of clientisation, information sharing and joint planning; 
- another pole of markets and networks characterized by inter-firm coordination of the processes of procurement, management and distribution of goods, services, information and investments; and long-term commitment to shared strategies.

Synthesizing the findings, we can highlight as key dimensions of emergent SCs

- inter-firm relationships among key actors, and

- chain information flows.

These elements are depicted in Figure 2, in which the arrow indicates the transition from an emergent status to a more developed one.

Figure 2 Emergent supply chains

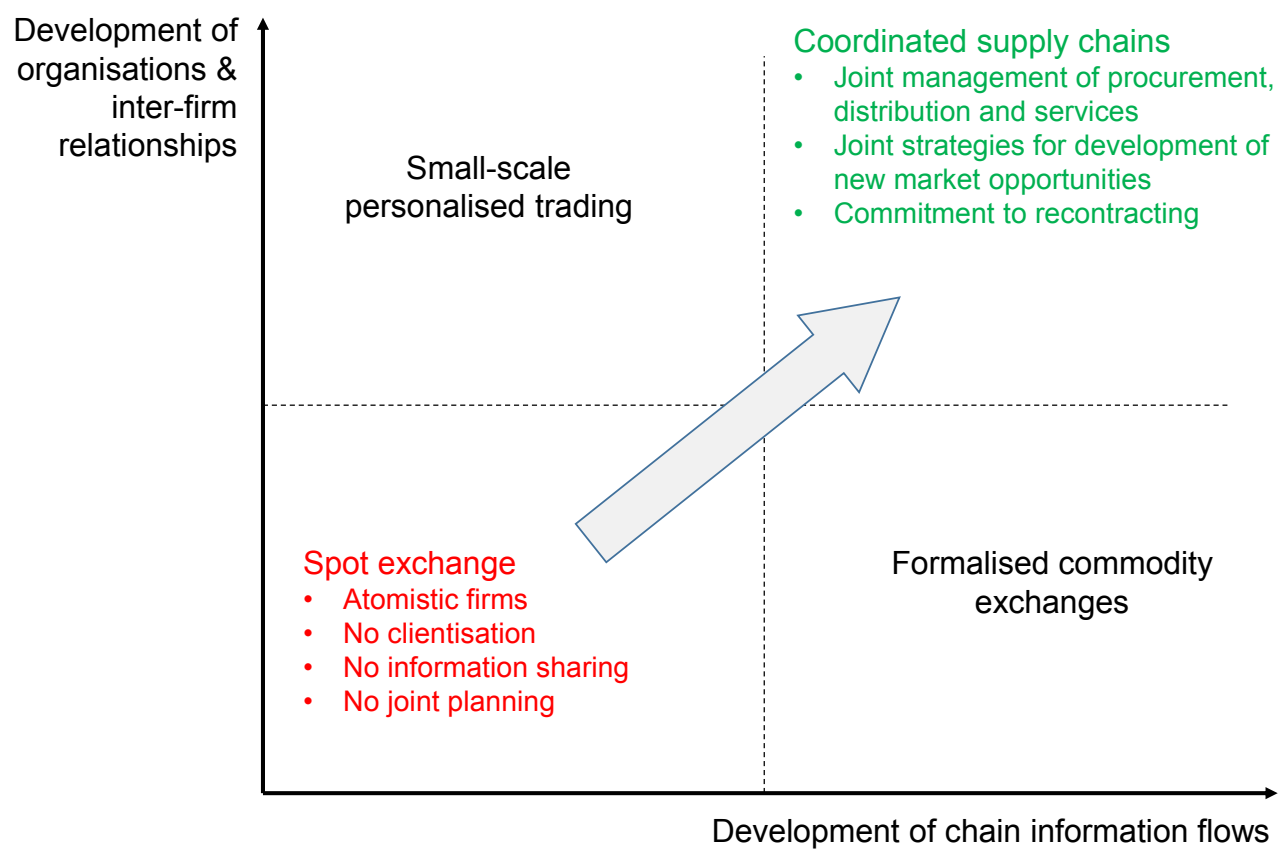

The conceptual contribution of this study goes wider by underlining the key differences on vital concepts between emergent and developed SCs. Blockage of information sharing due to the exercise of 'trader power' by certain stakeholders has been verified as an issue in emergent SCs. However unlike developed chains this does not come from the retailers but from the wholesalers and middlemen. Commitment issues in respect of new market opportunities were also confirmed, yet the differentiation in entrepreneurship in emergent SCs was directly related to the (lack of) recognition of the organic market as a new opportunity. Problematic collaboration and coordination originated in mistrust which makes these issues a common problem in both developed and emergent SCs. Nonetheless, it was a paradox that the majority of the stakeholders either did not acknowledge the issue or suggested that the failure was at a different level of the SC. Among SC participants, it was only the producers who realized the importance of horizontal coordination, yet most were insufficiently motivated to address this weakness constructively. The attitude of most SC actors was resignation. 


\section{Managerial Implications}

The question is, can anything be done to stimulate change? It will be a challenge to develop effective supply chain management where acute self-interest competes with cheating ("end of story", according to one of the greengrocers). The analysis does suggest entry points for a manifesto of small business development of widespread relevance in developing and emerging markets undergoing economic adjustment. While action presupposes a commitment from the public authorities to develop the sector, there are limits to what policy makers can do for emergent agrifood SCs. Greece participates in the European Union Common Agricultural Policy which provides substantial expenditure through different forms of direct payments to farmers ( $€ 2,315$ million in 2012) as well as crop specific market measures ( $€ 67$ million), more than one-third of which was spent on fruits and vegetables (European Commission, 2014). Conditioning the payment of such resources to structural change among primary suppliers, collective organisation and collaborative SC relationships would parallel the initiatives of many international organisations and donors to link producers more successfully to SCs in developing countries which share many of the characteristics of emergence seen in Greece (Coles and Mitchell, 2011; Helmsing and Vellema, 2011; Poole, 2013; All ACP Agricultural Commodities Programme (undated)).

Below there are key managerial implications based on the Greek case that can be applied in similar sectors in EU and developing economies sharing emergent SC characteristics.

\section{- Facilitation}

A supportive business environment with appropriate institutions to minimize transaction costs is a public good (Ring et al., 2010). There is a facilitatory role for the public sector to promote business, expand the agricultural economy, manage natural resources sustainably, and improve food quality. Policy makers should realize that any measure contributing to shift emergent SCs towards a more developed configuration is beneficial not only for the members of the SC per se, but for the wider economy. A strategically designed policy should include actions for the entire SC aiming to educate and support every member of the SC. The ultimate objective is for every SC member to embrace the value of targeting common goals and maximization of the overall SC performance.

In the case of Greece, any policy incentives should be directed towards younger and potentially more innovative individuals, rural youth who are prepared to take risks by entering and developing the industry, not least, but not just, because other remunerative rural opportunities are few. External support presupposes minimum thresholds of commitment and counterpart-contributions (such as land), and criteria for age and levels of education. Advocacy and training can be shaped around the few firms that are inserted in functioning new product SCs. Small business creation requires boosting the levels of technical and business knowledge (Lyson et al., 2008), and importantly, concessionary finance from public and private sources, possibly through loan arrangements guaranteed by the public sector institutions.

- Coordination structures 
Such investments can also be linked to incentives for interested parties to form a sectoral entity for organics that spans the whole SC. Above all other initiatives, such an approach can facilitate a dialogue on individual and common perceptions and problems, and create the awareness and trust that are prerequisites of joint action. An 'interprofessional' organisation (such as the more advanced French and Spanish "interprofessional" organizations) can be the mechanism for bringing together participants in the whole SC: a forum for information sharing about new market opportunities and product supply and demand characteristics; and for linking potential SC partners who share a vision for new opportunities such as organics. For the Greek agrifood sector this could be a register of firms interested in organics and similar added-value products. Exchanging know-how via this platform will enhance a wider availability of accurate (electronic) information resources on such organic principles and practices, and enable joint enterprise in researching consumer demand and preferences.

\section{- Supply chain leadership}

Leadership by the private sector is essential. The chain literature - for example Kaplinsky (2000), Humphrey (2005) - would suggest a buyer (like a supermarket) as "lead firm". In Greek organics the first-mover advantages might appeal to an innovative trader or specialized retailer, or less likely, an innovative producer organization. In the end, it is not individual firms but individual people - entrepreneurs - such as 'organic champions', for example, who will drive change. Changing sectoral structures is mostly a matter of incentives.

Getting business going is not just a matter of skills and knowledge, but an entrepreneurial predisposition, as has been shown elsewhere (Poole et al., 2013). Like trust, the willingness and ability to establish good relationships that underlie supply chain management are neither necessarily nor ordinarily innate; they are something that definitely can be learnt, but less easily taught. Even this psychology must be factored into a manifesto for small business development.

\section{Limitations}

The study has inevitable limitations. While the strength and coherence of the body of evidence about the lack of effective supply chain management in Greek organic citrus is compelling, as an exploratory study, the sampling constraints in particular suggest that caution should be exercised in extrapolating conclusions elsewhere. Nevertheless, the strategies proposed to boost the SMEs in the agrifood sector are likely to be widely applicable not just in the Greek agrifood sector but in other economies and regions where entrepreneurial supply chain management is in its infancy.

\section{References}

Adamowicz, M. \& Lemanowicz, M. (2006). Producer groups as a form of entrepreneurship and a tool for strengthening the competitive position of private farms in Poland. In: BIJMAN, J. (ed.) International agri-food chains and networks : management and organization. Wageningen: Wageningen Academic Publishers.

All ACP Agricultural Commodities Programme (undated). Towards Stronger ACP Agricultural Value Chains (A Programme Completion Report). Brussels, All ACP 
Agricultural Commodities Programme, c/o Cardno Emerging Markets Belgium. Retrieved 23 May 2014, from http://www.euacpcommodities.eu/files/AAACP_Completion_Report.pdf.

Anastasiadis, F. \& Poole, N. (2007). Supply Chain Inefficiencies in Greek Organic Food Industry: the Role of Information Flows. Adding Value to the Agro-food Supply Chain in the Future Euromediterranean Space, 103rd EAAE Seminar. Barcelona.

Ashby, A., Leat, M. \& Hudson-Smith, M. (2012). Making connections: a review of supply chain management and sustainability literature. Supply Chain Management: An International Journal, 17, 497-516.

Avlonitis, G. J. \& Salavou, H. E. (2007). Entrepreneurial orientation of SMEs, product innovativeness, and performance. Journal of Business Research, 60, 566-575.

Baker, W. E. \& Sinkula, J. M. (2009). The Complementary Effects of Market Orientation and Entrepreneurial Orientation on Profitability in Small Businesses. Journal of Small Business Management, 47, 443-464.

Barratt, M. (2004). Understanding the meaning of collaboration in the supply chain. Supply Chain Management: An International Journal, 9, 30-42.

Bijman, J. (2006). International agri-food chains and networks : management and organization, Wageningen, Wageningen Academic Publishers.

Bourlakis, M., Maglaras, G. \& Fotopoulos, C. (2012). Creating a "best value supply chain"? Empirical evidence from the Greek food chain. International Journal of Logistics Management, The, 23, 360-382.

Bourlakis, M. A. \& Bourlakis, C. A. (2001). Deliberate and emergent logistics strategies in food retailing: a case study of the Greek multiple food retail sector. Supply Chain Management: An International Journal, 6, 189-200.

Brindley, C. \& Oxborrow, L. (2014). Aligning the sustainable supply chain to green marketing needs: A case study. Industrial Marketing Management, 43, 45-55.

Brockman, B. K., Jones, M. A. \& Becherer, R. C. (2012). Customer Orientation and Performance in Small Firms: Examining the Moderating Influence of Risk-Taking, Innovativeness, and Opportunity Focus. Journal of Small Business Management, 50, 429-446.

Brunetto, Y. \& Farr-Wharton, R. (2007). The Moderating Role of Trust in SME Owner/Managers' Decision-Making about Collaboration. Journal of Small Business Management, 45, 362-387.

Burt, S. L. \& Sparks, L. (2003). Power and Competition in the UK Retail Grocery Market. British Journal of Management, 14, 237-254.

Cai, S., Jun, M. \& Yang, Z. (2010). Implementing supply chain information integration in China: The role of institutional forces and trust. Journal of Operations Management, 28, 257-268.

Chapman, R. L. \& Corso, M. (2005). From continuous improvement to collaborative innovation: the next challenge in supply chain management. Production Planning \& Control, 16, 339-344.

Chen, I. J. \& Paulraj, A. (2004). Towards a theory of supply chain management: the constructs and measurements. Journal of Operations Management, 22, 119-150.

Cheng, J.-H. (2011). Inter-organizational relationships and information sharing in supply chains. International Journal of Information Management, 31, 374-384.

Choi, T. Y. \& Wu, Z. (2009). Triads in supply networks: theorizing buyer-supplier-supplier relationships. Journal of Supply Chain Management, 45, 8-25.

Coles, J. and Mitchell, C., Eds. (2011). Markets and Rural Poverty: Upgrading in Value Chains. London and Ottawa, Earthscan and International Development Research 
Centre.Dimitriadis, N. I. \& Koh, S. C. L. (2005). Information flow and supply chain management in local production networks: the role of people and information systems. Production Planning \& Control, 16, 545-554.

Etemad, H. (2013). The process of internationalization in emerging SMEs and emerging economies, Cheltenham, Edward Elgar.

EU. (2012). Competition and commodity price volatility $D A F / C O M P / G F / W D(2012) 45$ [Online]. Organisation for Economic Co-operation and Development Available: http://ec.europa.eu/competition/international/multilateral/2012_feb_price.pdf [Accessed 6/2/2014.

European Commission (2013). Agriculture in the European Union. Statistical and Economic Information, Directorate-General for Agriculture and Rural Development. Retrieved 02 February 2015, from http:// European Commission (2014). Agriculture in the European Union and the Member States - Statistical factsheets. Greece, DirectorateGeneral for Agriculture and Rural Development. Accessed 02 February 2015, from http://ec.europa.eu/agriculture/statistics/factsheets/pdf/el_en.pdf.

European Commission (2014). Agriculture in the European Union and the Member States Statistical factsheets. Greece, Directorate-General for Agriculture and Rural Development. Accessed 02 February 2015, from http://ec.europa.eu/agriculture/statistics/factsheets/pdf/el_en.pdf.Feltham, T. S., Feltham, G. \& Barnett, J. J. (2005). The Dependence of Family Businesses on a Single Decision-Maker. Journal of Small Business Management, 43, 1-15.

Ghisi, F. A., Martinelli, D. P. \& Kristensen, T. (2006). Horizontal cooperation among small and medium-sized supermarkets as a tool for strengthening competitivenes. In: BIJMAN, J. (ed.) International agri-food chains and networks : management and organization. Wageningen: Wageningen Academic Publishers.

Glaser, B. G. \& Strauss, A. L. (1968). The Discovery of grounded theory. Strategies for qualitative research, Weidenfeld \& Nicolson: London.

Hawkes, C. (2009). Identifying Innovative Interventions to Promote Healthy Eating Using Consumption-Oriented Food Supply Chain Analysis. Journal of Hunger \& Environmental Nutrition, 4, 336-356.

Helmsing, A.H.J. and Vellema, S., Eds. (2011). Value Chains, Social Inclusion and Economic Development: Contrasting Theories and Realities. London, Routledge.

Herscovitch, L. \& Meyer, J. P. (2002). Commitment to organizational change: Extension of a three-component model. Journal of Applied Psychology, 87, 474-487.

Hsu, C.-C., Tan, K. C., Zailani, S. H. M. \& Jayaraman, V. (2013). Supply chain drivers that foster the development of green initiatives in an emerging economy. International Journal of Operations \& Production Management, 33, 656-688.

Huang, T.-T., Chen, L., Stewart, R. A. \& Panuwatwanich, K. (2013). Leveraging power of learning capability upon manufacturing operations. International Journal of Production Economics, 145, 233-252.

Humphrey, J. (2005). Shaping Value Chains for Development: Global Value Chains in Agribusiness, Eschborn, Germany, GTZ.

ICAP (2011). Financial sector study for organic farming and organic products (in Greek). Athens: ICAP.

Iyer, A., Lee, H. L. \& Roth, A. (2013). Introduction to Special Issue on POM Research on Emerging Markets. Production and Operations Management, 22, 233-235.

Jraisat, L., Gotsi, M. \& Bourlakis, M. (2013). Drivers of information sharing and export performance in the Jordanian agri-food export supply chain: A qualitative study. International Marketing Review, 30, 323-356. 
Kahneman, D., Slovic, P. \& Tversky, A. (1982). Judgement under uncertainty : heuristics and biases, Cambridge, Cambridge University Press.

Kaplinsky, R. (2000). Spreading the gains from globalisation: what can be learned from value chain analysis. IDS Working Paper No. 10. Brighton, Institute of Development Studies.

Lamprinopoulou, C., Tregear, A. \& Ness, M. (2006). Agrifood SMEs in Greece: the role of collective action. British Food Journal, 108, 663-676.

Lee, H. L. (2004). The triple-A supply chain. Harvard Business Review, 102-112.

Li, D. \& O'brien, C. (1999). Integrated decision modelling of supply chain efficiency. International Journal of Production Economics, 59, 147-157.

Liberman-Yaconi, L., Hooper, T. \& Hutchings, K. (2010). Toward a Model of Understanding Strategic Decision-Making in Micro-Firms: Exploring the Australian Information Technology Sector. Journal of Small Business Management, 48, 70-95.

Little, R., Maye, D. \& Ilbery, B. (2010). Collective purchase: moving local and organic foods beyond the niche market. Environment and Planning A, 42, 1797-1813.

Lorentz, H., Kittipanya-Ngam, P. \& Singh Srai, J. (2013). Emerging market characteristics and supply network adjustments in internationalising food supply chains. International Journal of Production Economics, 145, 220-232.

Lumpkin, G. T. \& Dess, G. G. (1996). Clarifying the entrepreneurial orientation construct and linking it to performance. Academy of Management Review, 21, 135-172.

Lyson, T. A., Stevenson, G. W. \& Welsh, R. (2008). Food and the mid-level farm : renewing an agriculture of the middle, Cambridge, Mass. ; London, MIT.

Malhotra, N. K. (2010). Marketing research : an applied orientation, Upper Saddle River, NJ ; London, Prentice Hall.

March, J. G. \& Simon, H. A. (1993). Organizations, Blackwell.

Matopoulos, A., Vlachopoulou, M., Manthou, V. \& Manos, B. (2007). A conceptual framework for supply chain collaboration: empirical evidence from the agri-food industry. Supply Chain Management: An International Journal, 12, 177-186.

Mena, C., Humphries, A. \& Choi, T. Y. (2013). Toward a Theory of Multi-Tier Supply Chain Management. Journal of Supply Chain Management, 49, 58-77.

Morgan, R. M. \& Hunt, S. D. (1994). The Commitment-Trust Theory of Relationship Marketing. Journal of Marketing, 58, 20.

North, D. C. (1990). Institutions, Institutional Change and Economic Performance, Cambridge, Cambridge University Press.

Nyaga, G. N., Whipple, J. M. \& Lynch, D. F. (2010). Examining supply chain relationships: Do buyer and supplier perspectives on collaborative relationships differ? Journal of Operations Management, 28, 101-114.

Ortiz-Miranda, D., Moreno-Perez, O. M. \& Moragues-Faus, A. M. (2010). Innovative strategies of agricultural cooperatives in the framework of the new rural development paradigms: the case of the Region of Valencia (Spain). Environment and Planning A, 42, 661-677.

Patzelt, H. \& Shepherd, D. A. (2011). Recognizing Opportunities for Sustainable Development. Entrepreneurship Theory and Practice, 35, 631-652.

Poole, N.D. (2013). Value chain perspectives and literature: a review. Food Chain 3(3): 199211.

Poole, N. \& Donovan, J. (2014). Building cooperative capacity: the speciality coffee sector in Nicaragua. Journal of Agribusiness in Developing and Emerging Economies, (Forthcoming) 
Poole, N. D., Chitundu, M. \& Msoni, R. (2013). Commercialisation: A meta-approach for agricultural development among smallholder farmers in Africa? Food Policy, 41, $155-$ 165.

Prajogo, D., Chowdhury, M., Yeung, A. C. L. \& Cheng, T. C. E. (2012). The relationship between supplier management and firm's operational performance: A multidimensional perspective. International Journal of Production Economics, 136, 123 130.

Pullman, M. E. \& Dillard, J. (2010). Values based supply chain management and emergent organizational structures. International Journal of Operations \& Production Management, 30, 744-771.

Rauch, A., Wiklund, J., Lumpkin, G. T. \& Frese, M. (2009). Entrepreneurial Orientation and Business Performance: An Assessment of Past Research and Suggestions for the Future. Entrepreneurship Theory and Practice, 33, 761-787.

Ring, J. K., Peredo, A. M. \& Chrisman, J. J. (2010). Business Networks and Economic Development in Rural Communities in the United States. Entrepreneurship Theory and Practice, 34, 171-195.

Rong, A., Akkerman, R. \& Grunow, M. (2011). An optimization approach for managing fresh food quality throughout the supply chain. International Journal of Production Economics, 131, 421-429.

Rostow, W. W. (1960). The Stages of Economic Growth: A Non-Communist Manifesto, Cambridge, Cambridge University Press.

Roth, A. V., Tsay, A. A., Pullman, M. E. \& Gray, J. V. (2008). Unraveling the food supply chain: strategic insights from china and the 2007 recalls. Journal of Supply Chain Management, 44, 22-39.

Saldaña, J. (2013). The coding manual for qualitative researchers, Los Angeles, [Calif.] ; London, SAGE.

Sarac, A., Absi, N. \& Dauzère-Pérès, S. (2010). A literature review on the impact of RFID technologies on supply chain management. International Journal of Production Economics, 128, 77-95.

Sartorius, K. \& Kirsten, J. (2007). A framework to facilitate institutional arrangements for smallholder supply in developing countries: An agribusiness perspective. Food Policy, 32, 640-655.

Schermerhorn, J. R. (2002). Management, New York, Wiley.

Shane, S. \& Venkataraman, S. (2000). The promise of entrepreneurship as a field of research. Academy of Management Review, 25, 217-226.

Sharifi, H., Ismail, H. S., Qiu, J. \& Najafi Tavani, S. (2013). Supply chain strategy and its impacts on product and market growth strategies: A case study of SMEs. International Journal of Production Economics, 145, 397-408.

Silverman, D. (2006). Interpreting qualitative data : methods for analysing talk, text and interaction, London, SAGE.

Simon, M., Miree, C. \& Dule, M. (2012). La Vida Local: Planting the Seeds for Growing an Organic Food Delivery Business. Entrepreneurship Theory and Practice, 37, 641660.

Slater, S. F. \& Narver, J. C. (1994). Does Competitive Environment Moderate the Market Orientation-Performance Relationship. Journal of Marketing, 58, 46-55.

Smith, A. (2006). Green niches in sustainable development: the case of organic food in the United Kingdom. Environment and Planning C: Government and Policy, 24, 439458. 
Soosay, A. C., Hyland, W. P. \& Ferrer, M. (2008). Supply chain collaboration: capabilities for continuous innovation. Supply Chain Management: An International Journal, 13, 160-169.

Svensson, G. \& Wagner, B. (2012). Implementation of a sustainable business cycle: the case of a Swedish dairy producer. Supply Chain Management: An International Journal, 17, 93-97.

Taylor, D. H. (2006). Strategic considerations in the development of lean agri-food supply chains: a case study of the UK pork sector. Supply Chain Management: An International Journal, 11, 271-280.

Taylor, D. H. \& Fearne, A. (2009). Demand management in fresh food value chains: a framework for analysis and improvement. Supply Chain Management: An International Journal, 14, 379 - 392.

Vasileiou, K. \& Morris, J. (2006). The sustainability of the supply chain for fresh potatoes in Britain. Supply Chain Management: An International Journal, 11, 317 - 327.

Vranaki, G. (2009). Greek Organic Agriculture Statistics [Online]. Athens: www.minagric.gr. [Accessed 16-09-2009 2009].

Wernerfelt, B. (1984). A resource-based view of the firm. Strategic Management Journal, 5, 171-180.

Willer, H. \& Yussefi, M. (2013). The World of Organic Agriculture. Statistics and Emerging Trends 2011, Bonn Germany, International Federation of Organic Agriculture Movements (IFOAM).

Williamson, O. E. (1975). Markets and hierarchies: Analysis and antitrust implications. , New York: Free Press.

Williamson, O. E. (1979). Transaction-Cost Economics - Governance of Contractual Relations. Journal of Law and Economics, 22, 233-261.

Wong, C., Skipworth, H., Godsell, J. \& Achimugu, N. (2012). Towards a theory of supply chain alignment enablers: a systematic literature review. Supply Chain Management: An International Journal, 17, 419-437.

Wu, Z. \& Pagell, M. (2011). Balancing priorities: Decision-making in sustainable supply chain management. Journal of Operations Management, 29, 577-590.

Yang, J. (2011). A structural model of supply chain performance in an emerging economy. International Journal of Production Research, 50, 3895-3903.

Yin, R. K. (2003). Case study research : design and methods, Thousand Oaks, Calif.; London, SAGE.

Yin, R. K. (2012). Applications of case study research, London, SAGE. 


\section{Appendix: Interview guides}

1. Retailers - Greengrocery

A. Company/store details

A1) Name / position / education?

A2) Number of employees?

A3) How many years in the business?

A4) How much of the business is organic (\%)?

A5) Quantities of citrus trading?

A6) How much of the citrus is organic (\%) now and/or in last 4-5 months?

B. Pricing, promotion, positioning

B1) Pricing. Decision mechanism?

B1a) What pricing model you use: a fixed margin, cost plus \%?

B1b) Other alternative, different prices during day etc.?

B1c) Would you check competitor's prices?

B2) Do you have a specific promotion strategy?

B3) Positioning of the products on shelf?

B4) Organic price difference compared to conventional:

B4a) is it justified?

B4b) how much it should be?

C. Retailers' perceptions of what consumers really want

C1) Standard customers:

C2) Occasional customers:

C3) Do you know what your customer really wants?

C3a) How?

$\mathrm{C} 3 \mathrm{~b})$ Survey consumers?

C3c) Operate a system whereby consumer can make suggestions?

C3d) Read market research?

C4) Do you have any kind of data from your store sales?

C5) Do you analyse these data?

C6) Do you get any feedback from your customers?

C7) How are you dealing with that feedback?

C8) Through which process do you make decisions regarding the products you are selling?

D. Retailers' perceptions of supply (distribution channels).

D1) Where do you buy organic citrus?

D2) Availability of organic citrus in the wholesale market?

D3) Relationship with the suppliers, have a specific wholesaler you work with or do you 'go around' the market?

D4) Quality control?

D5) Quality assurance?

D6) Seasonality?

D7) Other issues?

E. Retailers' perceptions of organic farming

E1) Definition of organic products?

E1a) Explore different aspects if not mentioned in the definition by him/her (i.e. environmental impact):

E2) If you haven't in the past, will you ever introduce organic in you store?

E3) What do you think about organic products?

E4) Other issues with organics?

F. Other issues, remarks etc. 
F1) Reasons why not promoting/introducing more organic?

F2) Problems with organic fruits?

2. Wholesalers - Trading company

A. Company details

A1) Name / position / education?

A2) Number of employees?

A3) Location of the company's headquarters?

A4) Number of stores/warehouses?

A5) Functions?

Exports: Packing:

Imports: $\quad$ Storing:

Distribution: Transportation:

Wholesaling: Other (specify):

A6) How many years in the business?

A7) Which products are you trading?

A8) Why these products?

A9) Quantities of citrus trading?

A10) How much of the citrus is organic (\%)?

A11) Figures on turnover or sales volumes?

B. Supply issues

B1) Suppliers (number \& names)?

B2) Relationships with supplies?

B3) Specific suppliers or not?

B4) Criteria to select a supplier?

B5) Problems with supply?

B6) Availability of products?

B7) Seasonality?

B8) Traceability?

B9) Quality control?

B10) Quality assurance?

B11) Branding?

B12) Imports

B12a) Why?

B12b) Country of origin:

B12c) Suppliers:

B12d) Criteria to select a supplier:

B12e) Problems with supply:

B12f) Seasonality:

B12g) Traceability:

B12h) Which products:

B12i) Quality control:

B12j) Quality assurance:

B12k) Other:

C. Trading issues

C1) Customers

C1a) Specific or not?

C1b) Standard (\%)

$\mathrm{C} 1 \mathrm{c})$ Occasional (\%)

C1d) Relationships? 
C1e) Region $\backslash$ city of their stores?

C1f) What kind of stores/business they have?

- $\quad$ Specialized stores (\%):

- $\quad$ Greengroceries (\%):

- $\quad$ Super markets $(\%)$ :

- $\quad$ Open markets (\%):

- $\quad$ Exports $(\%)$ :

- $\quad$ Other $(\%)$ :

C2) Pricing

C2a) What pricing model you use: a fixed margin, cost plus \%, comparison with competitors?

$\mathrm{C} 2 \mathrm{~b})$ Other alternative?

C8) End-consumer demand.

C8a) Do you know what consumers really want?

$\mathrm{C} 8 \mathrm{~b})$ Feedback from retailers?

C8c) Survey consumers?

C8d) Read market research?

C9) Promotion

D. Perceptions of organics

D1) Definition of organic products?

D1a) Explore different aspects if not mentioned in the definition by him/her (i.e. environmental impact):

D2) Future of organic products/market?

E. Other issues, remarks etc.

3. Producers

A. Farm details

A1) Name / education?

A2) What proportion of your income/time/economic activity is taken up with farming?

A3) Are you a member of a cooperative organisation?

A4) Region?

A5) What kind of cultivations?

Cultivation Stremmas $(0.1$ hectares $) \quad$ Yield (tons/year)

Orange

Mandarin

Lemon

A6) Why these cultivations?

A7) How many years in the fields?

A8) Since when organic?

A9) How many employees?

B. Supply issues

B1) Where do you sell?

Wholesaler in the farm or in the factory (\%):

Wholesaler in the market $(\%)$ :

Open market by yourself $(\%)$ :

Open market by other (trader or middleman) (\%):

Cooperative (\%):

Direct to consumer in the farm or else (\%):

B2) Criteria in order to decide where to sell?

B3) Satisfied with the current distribution channels?

B4) Problems in the supply? 
- $\quad$ Lack of knowledge of market conditions?

- $\quad$ Poor transport and infrastructure?

- Losses?

- $\quad$ Theft/other insecurity?

- $\quad$ Default by buyers?

- $\quad$ Low prices?

- $\quad$ Delayed payments?

- $\quad$ Few alternative outlets?

B5) Suggestions in order to solve these problems?

C. Cost \& pricing issues

C1) How do you evaluate the prices offered by the buyer?

C2) Do you calculate the cost $/ \mathrm{kg}$ for your products?

C3) Are you aware of the daily market prices?

C4) Are you aware of the consumer demand?

C5) Do you have any awareness/specific knowledge of market trends?

D. Perception of organics

D1) Why organic?

D2) Explore different aspects if not mentioned by him/her (i.e. environmental impact)?

D3) Problems related to organics:

D4) How do producers assure the organic quality of their produce vis-a vis traders?

E. Other

E1) Certification (cost, satisfied etc.):

E2) Support:

E3) Are you aware of any national Greek or EU incentives or other policy mechanisms that affect whether you produce organic or conventional?

E3) Subsidies:

E4) Compared to conventional what do you think about:

- Yield:

- $\quad$ Phyto-sanitary issues:

- Prices:

- $\quad$ Chemical inputs:

- $\quad$ Management time:

- $\quad$ The motivation in terms of premium and penalties: 